\title{
INTERNATIONAL CRIMINAL LAW AND NEW ZEALAND REFUGEE STATUS DETERMINATIONS: A CASE NOTE ON ATTORNEY-GENERAL V TAMIL $X$
}

\section{Ella Watt*}

\begin{abstract}
This article considers Attorney-General v Tamil X, a recent New Zealand Supreme Court decision on refugee status determinations. Specifically, it considers the approach taken to art $1 F$ of the Refugee Convention in decisions on the exclusion of claimants from refugee status. As claims are increasingly affected by art $1 F$ considerations, it is imperative that the law in this complicated area is clear and just. This article traces Tamil X's advancement through the courts, and presents an analysis of the Supreme Court's judgment. The article also recommends some future developments for the jurisprudence on the exclusion clauses, specifically the adoption of a modified version of the ICTY jurisprudence on joint criminal enterprise.
\end{abstract}

\section{INTRODUCTION}

Refugee law protects the most vulnerable people in society. It provides, for those who fear persecution in their home States, a catalogue of rights and protections in a safe country elsewhere. It aims to ensure that those who cannot be protected by their State, through no fault of their own, will be protected by the international community. But conflicts are increasingly complex, and atrocities are frequently committed by both sides in combat. Fault is becoming harder to determine and it is harder and harder to distinguish the persecutors from the persecuted.

In this context, Attorney-General $v$ Tamil $X$ is an important recent decision of the Supreme Court of New Zealand. ${ }^{1}$ The case addressed art $1 \mathrm{~F}$ of the Convention Relating to the Status of

* Submitted as part of the LLB(Hons) programme at Victoria University of Wellington. Recipient of the 2011 Robert Orr McGechan Prize for the Best Work for the Victoria University of Wellington Law Review. I would like to thank my supervisor Alberto Costi for his help.

1 Attorney-General v Tamil X [2010] NZSC 107, [2011] 1 NZLR 721. 
Refugees 1951 (the Refugee Convention), ${ }^{2}$ which excludes war criminals and the perpetrators of serious non-political crimes from refugee status. Efforts are made for global consistency in the application of the Refugee Convention, so the Tamil $X$ decision, which created an effective fusion of the law on art $1 \mathrm{~F}$ from several jurisdictions, will be a leading decision in New Zealand and internationally.

In New Zealand particularly, under the Immigration Act 2009, there is currently substantial doubt about the protection which will be given to excluded asylum seekers. The application of the exclusion clauses will determine who is granted refugee status, and who is potentially returned to face persecution, torture or arbitrary deprivation of life. In our "new world disorder", ${ }^{3}$ the clear and appropriate application of art $1 \mathrm{~F}$ is vital for the protection of genuine refugees.

This article will first present the facts of the case and follow the progression of Tamil $X$ through the courts. In doing so, this article will not address questions of the standard of judicial review, though they are raised in the case, but will focus on the impact of international criminal law on refugee status determinations under art $1 \mathrm{~F}$. Secondly, it will analyse the Supreme Court's approach to art $1 \mathrm{~F}$ in the case. Finally, it will assess whether the Supreme Court's approach is the best way to protect refugees, and will conclude by making several suggestions for improvements to the law as stated in Tamil $X$.

\section{A REVIEW OF TAMIL X}

\section{A Facts}

$\mathrm{X}$ is a citizen of Sri Lanka, who made an application for refugee status in New Zealand in 2001. The relevant facts began in 1992, when he served as the Chief Engineer on the MV Yahata, the "finest vessel" owned by the Tamil Tigers. ${ }^{4}$ This vessel repeatedly travelled routes in South Asia, transporting standard commercial goods, as well as munitions and weapons for the Tamil Tigers' use. On only one occasion is it certain that the vessel carried arms and munitions, and this is on the Yahata's last voyage. ${ }^{5} \mathrm{X}$ claims that he was unaware of the cargo the Yahata carried prior to the final voyage, and that he had no knowledge of the nature of the cargo when the final voyage from Phuket began. Soon after departure, he was informed that the vessel belonged to the Tamil Tigers

2 Convention Relating to the Status of Refugees 189 UNTS 137 (adopted 28 July 1951, entered into force 22 April 1954).

3 James C Hathaway and Colin J Harvey "Framing Refugee Protection in the New World Disorder" (2001) 34 Cornell Int LJ 257 at 257.

4 Refugee Appeal No 74796 RSAA 74796, 19 April 2006 at [31].

5 Attorney-General $v$ Tamil X, above n 1, at [78]. 
and was carrying arms and munitions. He was also informed that he could not leave until the ship arrived in Sri Lanka. ${ }^{6}$

Before reaching Sri Lanka, the ship was intercepted by the Indian coast-guard. They requested to board the vessel, were denied access and were warned that the vessel carried 110 tonnes of explosives. ${ }^{7}$ The Yahata fled, followed by several Indian Navy vessels, eventually anchoring near Chennai, India. After a small-arms fire fight, the Yahata caught alight. $\mathrm{X}$ and the rest of the crew abandoned the vessel, and were subsequently rescued from the ocean and placed in custody. The 10 Tamil Tigers members who had boarded at Phuket remained on board, and perished as the ship sank. $^{8}$

$\mathrm{X}$ and others were prosecuted in the Indian courts, and $\mathrm{X}$ served three years imprisonment for his role in the destruction of the vessel. ${ }^{9}$ Having served his sentence he left India for Singapore, and Singapore for New Zealand, arriving on a visitor's permit on 13 September 2001. ${ }^{10}$ Shortly afterwards, his wife and children arrived in New Zealand on visitor's visas, and X made an application for refugee status for himself and his family. $\mathrm{X}$ was denied refugee status in the first instance for lack of satisfaction of a real chance that he would be persecuted if he returned to Sri Lanka. If denied refugee status, Yarwood states that $\mathrm{X}$ and his wife risked being "returned to the[ir] state of origin with the shadow of ... [their] crimes hanging above them". ${ }^{11}$ Seeking protection, $\mathrm{X}$ appealed the decision before the Refugee Status Appeals Authority (the RSAA).

\section{B The Refugee Status Appeals Authority Decision}

At the RSAA, $\mathrm{X}$ was found to have been complicit in crimes against humanity committed by the Tamil Tigers. ${ }^{12} \mathrm{X}$ accepted before the RSAA that he was aware of the Tamil Tigers' crimes against humanity. However, he denied being a Tamil Tigers supporter, denied he knew that the Yahata was a Tamil Tigers' vessel when the final voyage began, and denied any knowledge of the nature of the cargo that he was transporting. ${ }^{13}$

6 Refugee Appeal No 74796, above n 4, at [41].

7 At [55].

8 At [45]

9 At [46].

10 At [47]

11 Lisa Yarwood "The Tamil X Case" [2010] NZLJ 7 at 7.

12 Refugee Appeal No 74796, above n 4, at [128].

13 At [43]. 
X's claims of lack of knowledge were not believed by the RSAA, ${ }^{14}$ which doubted that he would have been accepted to work on the vessel if the Tamil Tigers were uncertain of his loyalty, ${ }^{15}$ and that he could work aboard the ship for six months unaware of what cargo was carried. ${ }^{16}$ The RSAA stated that at best he "deliberately turned a blind eye to the obvious"17 and inferred that X was a trusted member of the Tamil Tigers.

The RSAA followed the Canadian authority from Musagera v Canada (Minister of Citizenship and Immigration $)^{18}$ on crimes against humanity, which required a proscribed act, committed as part of a widespread attack directed against civilians, in which the claimant participates knowing or risking that the widespread attack will occur. ${ }^{19}$ The RSAA excluded X from refugee status under art $1 \mathrm{~F}$ (a) because he knew that the arms which he was helping to smuggle would as likely as not be used by the Tamil Tigers to commit crimes against humanity. The RSAA therefore concluded that there were serious reasons for considering $\mathrm{X}$ was a knowing accomplice, ${ }^{20}$ and that he was liable as a party to crimes against humanity committed by the Tamil Tigers, by virtue of his participation as Chief Engineer of the Yahata. ${ }^{21}$

The RSAA also found that if its assessment under art $1 \mathrm{~F}$ (a) was incorrect, $\mathrm{X}$ was nevertheless excluded under art $1 \mathrm{~F}$ (b) due to his role in the destruction of the Yahata, an act which the RSAA ruled was "committed to destroy the vessel and its cargo and to thereby prevent their seizure",22 which they found not to constitute a political purpose.

\section{ARTICLE 1F OF THE REFUGEE CONVENTION}

This section will provide an overview of art $1 \mathrm{~F}$ in the context of the Refugee Convention. Generally, refugee status is granted to all persons who, "owing to a well-founded fear of being persecuted for reasons of race, religion, nationality, membership of a particular social group or political opinion", ${ }^{23}$ are outside their nation, and unable to return to it without fear for their safety or

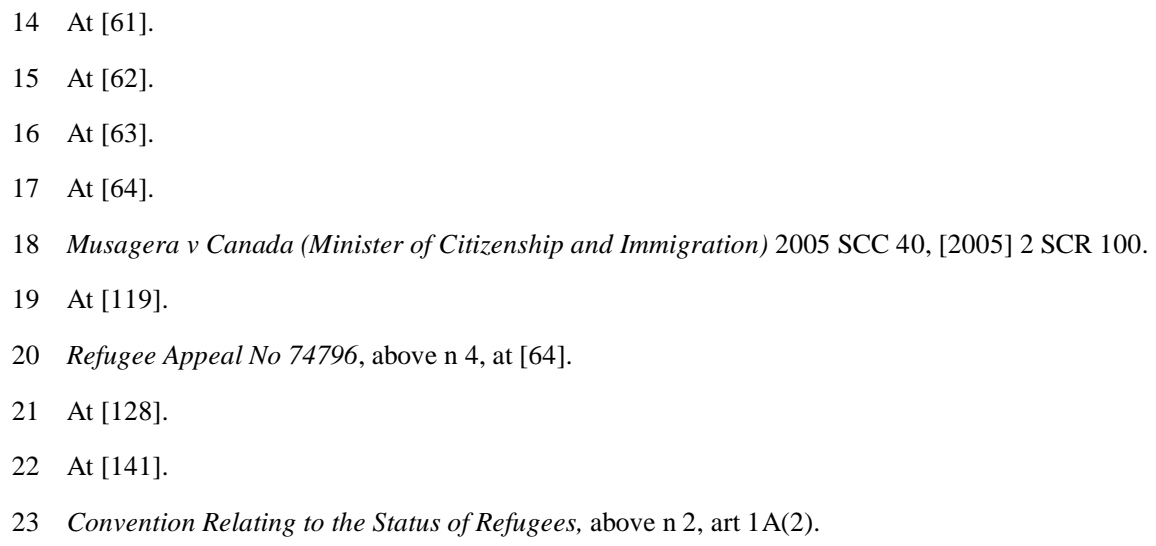


their lives. If refugee status is granted, rights similar to those of citizens ${ }^{24}$ or of legally present foreign nationals, ${ }^{25}$ as appropriate, are granted to the claimant under the Refugee Convention. Exceptions stating who cannot be granted refugee status are contained in arts $1 \mathrm{D}, 1 \mathrm{E}$ and $1 \mathrm{~F}$. Articles $1 \mathrm{D}$ and $1 \mathrm{E}$ deal with persons who are not in need of protection, while art $1 \mathrm{~F}$ deals with persons who are not deserving of protection. The present case is concerned with exclusion under art $1 \mathrm{~F}$ of the Refugee Convention, which reads: ${ }^{26}$

The provisions of this Convention shall not apply to any person with respect to whom there are serious reasons for considering that:

(a) He has committed a crime against peace, a war crime, or a crime against humanity, as defined in the international instruments drawn up to make provision in respect of such crimes;

(b) He has committed a serious non-political crime outside the country of refuge prior to his admission to that country as a refugee;

(c) He has been guilty of acts contrary to the purposes and principles of the United Nations.

There is an element of international morality implicit in art $1 \mathrm{~F}$ that is absent in the other exclusion clauses, which renders art $1 \mathrm{~F}$ controversial. ${ }^{27}$ It is a provision of "enormous complexity" ${ }^{28}$ due to the need to negotiate the cross-over between international criminal law, international human rights law, international humanitarian law and national immigration requirements in its application. The article is widely agreed to have a double purpose, an understanding of which is central to its correct application. The United Nations High Commission on Refugees, in its guidelines intended to provide interpretive guidance to governments, decisionmakers and the judiciary, states: ${ }^{29}$

The rationale behind the exclusion clauses is twofold. Firstly, certain acts are so grave that they render their perpetrators undeserving of international protection as refugees. Secondly, the refugee framework should not stand in the way of serious criminals facing justice.

24 Articles 4, 12, 14, 16(2), 20, 22, 23, 24 and 29.

25 Articles 7, 13, 15, 17, 18, 19, 21 and 26 .

26 Article 1F.

27 JC Hathaway The Law of Refugee Status (Butterworths, Toronto, 1991) at 214.

28 James C Simeon "Complicity and Culpability and the Exclusion of Terrorists from Convention Refugee Status Post-9/11" (2010) 29 Refugee Survey Quarterly 104 at 132.

29 United Nations High Commissioner for Refugees "Guidelines on International Protection: Application of the Exclusion Clauses: Article 1F of the 1951 Convention relating to the Status of Refugees" (4 September 2003) UNHCR The UN Refugee Agency < www.unhcr.org> at [3]. 
And in a passage adopted by the Supreme Court in Tamil $X$, James Hathaway, in his seminal work, describes the purpose of exclusion as: ${ }^{30}$

... rooted in both a commitment to the promotion of an international morality and a pragmatic recognition that states are unlikely to agree to be bound by a regime which requires them to protect undesirable refugees.

Following the Second World War, States shared a desire that "war criminals should not be protected", ${ }^{31}$ and to retain the ability to deny admission to their territory to criminals who may create a risk to society. ${ }^{32}$ The Refugee Convention is accepted to intend to exclude those who are deemed unworthy or "undeserving" 33 of international protection from refugee status. "Those whose acts have created refugees"34 and who can be described as morally culpable are excluded under art $1 \mathrm{~F}(\mathrm{a})$, while those excluded under art $1 \mathrm{~F}(\mathrm{~b})$ are considered "undesirable" 35 by States due to their criminality. If arts $1 \mathrm{~F}(\mathrm{a})$, (b) or (c) apply, an asylum seeker cannot be granted refugee status.

Any discussion of the application of the exclusion clauses in the Refugee Convention must consider the underlying tension that exists between exclusion under art $1 \mathrm{~F}$ and the concept of nonrefoulement as expressed in art 33 of the Refugee Convention, which reads: ${ }^{36}$

1. No Contracting State shall expel or return ("refouler") a refugee in any manner whatsoever to the frontiers of territories where his life or freedom would be threatened on account of his race, religion, nationality, membership of a particular social group or political opinion.

2. The benefit of the present provision may not, however, be claimed by a refugee whom there are reasonable grounds for regarding as a danger to the security of the country in which he is, or who, having been convicted by a final judgement of a particularly serious crime, constitutes a danger to the community of that country.

30 JC Hathaway The Law of Refugee Status, above n 27, at 214.

31 United Nations High Commissioner for Refugees Handbook on Procedures and Criteria for Determining Refugee Status under the 1951 Convention and the Protocol relating to the Status of Refugees (2nd ed, UNCHR, Geneva, 1988) at [148].

32 Ibid.

33 James C Simeon "Complicity and Culpability and the Exclusion of Terrorists from Convention Refugee Status Post-9/11", above n 28, at 112.

34 James C Simeon "Exclusion Under Article 1F(a) of the 1951 Convention in Canada" (2009) 21 IJRL 193 at 199.

35 JC Hathaway The Law of Refugee Status, above n 27, at 214.

36 Convention Relating to the Status of Refugees, above n 2, arts 33(1) and 33(2). 
This principle provides protection for legitimate refugees, prohibiting their return or refoulement to their country of origin, or any country in which they would be at risk of persecution or torture. Article 33(2) provides for an exception to protection from non-refoulement. If a refugee is deemed to be a danger to the security of the receiving country, or is convicted of a serious crime inside the country, that refugee can be returned despite the risk of persecution or torture.

The non-refoulement principle is non-derogable. ${ }^{37}$ However, as art 33 only applies to those who are found to be legitimate refugees under art 1 , art $1 \mathrm{~F}$ effectively creates a pre-admission exemption. If asylum seekers are excluded under art $1 \mathrm{~F}$, they have no right to protection from refoulement under the Refugee Convention. This is controversial, as it allows for refoulement to torture for those who are excluded from refugee status, despite the relationship of the non-refoulement provision to the absolute jus cogens prohibition on torture at international law. ${ }^{38}$ It is worth noting that although some commentators have argued that non-refoulement has also attained peremptory norm status, ${ }^{39}$ State party practice and the text of the Refugee Convention itself suggests that this is not the case. ${ }^{40}$

\section{DECISIONS ON TAMIL X IN THE LOWER COURTS}

\section{A The High Court}

In the High Court, the RSAA's decision in Tamil $X$ came under judicial review. The focus was on the RSAA's factual findings, and "little attention was paid to the correct legal test to be applied". ${ }^{41}$ The High Court concluded that it was reasonable for the RSAA to have found on the facts that $\mathrm{X}$ was complicit in crimes against humanity committed by the Tamil Tigers, ${ }^{42}$ and that he committed a serious non-political crime in sinking the Yahata, ${ }^{43}$ and so upheld the decision.

The reasoning of the High Court followed that of the RSAA, holding it was implausible that the Tamil Tigers would employ a Chief Engineer of whose loyalty they were uncertain, and that X must therefore have been a willing participant in the smuggling. ${ }^{44}$ Therefore, they concluded that he was dedicated to the Tamil Tigers' objectives and knowingly assisted in carrying them out, ${ }^{45}$ despite

37 Ibid at art 42(1).

38 Aoife Duffy "Expulsion to Face Torture - Non-Refoulement in International Law" (2008) 20 IJRL 373 at 379.

39 See for example Jean Allain "Jus Cogens Nature of Non-Refoulement" (2001) 13 IJRL 533.

40 Zaoui v Attorney-General (No 2) [2005] NZSC 38, [2006] 1 NZLR 289 at [51]; Aiofe Duffy "Expulsion to Face Torture - Non-Refoulement in International Law", above n 38, at 390.

41 Lisa Yarwood "The Tamil $X$ Case", above n 11, at 7.

42 X \& Yv Refugee Status Appeals Authority HC Auckland CIV-2006-404-4213, 17 December 2007 at [86].

43 At [99].

44 At [54].

45 At [85]. 
finding "no evidence of direct participation" 46 in the crimes by X. The High Court ruled that the RSAA was entitled to find serious reasons for considering that $\mathrm{X}$ was complicit in the crimes against humanity committed by the Tamil Tigers. ${ }^{47}$

The High Court, like the RSAA, followed Musagera, and held that there need be no link between a "specific event" 48 constituting a crime committed by the Tamil Tigers and X's actions; rather, his involvement with the group as a willing participant in the attempt to smuggle arms was sufficient. $^{49}$

The High Court also found that the RSAA reasonably held that X committed a serious, nonpolitical crime sufficient for exclusion under art $1 \mathrm{~F}(\mathrm{~b}),{ }^{50}$ relying on his conviction by the Supreme Court of India, and their reasonable inference from the evidence presented that $\mathrm{X}$ was a loyal Tamil Tigers supporter.

\section{B The Court of Appeal}

The Court of Appeal overturned the decision of the High Court and held that it was not open to the RSAA to find X complicit in crimes against humanity, war crimes, or serious non-political crimes. The Court found that the RSAA and the High Court had "misdirected themselves in law as to the proper approach to the issue of complicity". ${ }^{51}$ The Court declared the Canadian authority outdated, ${ }^{52}$ and instead adopted the reasoning from the English Court of Appeal decision in $R$ (JS (Sri Lanka)) v Secretary of State for the Home Department, ${ }^{53}$ a decision highly similar on the facts, which dealt with a Sri Lankan asylum seeker who had smuggled arms and personnel for the Tamil Tigers. Central to the analysis of all three judges at the Court of Appeal was whether the Refugee Convention standard of "serious reasons for considering" had been met. All the judges doubted that there was sufficient evidence for the standard to be satisfied.

Hammond $\mathrm{J}$ adopted the reasoning in the JS (Sri Lanka) judgment. He ruled that finding "serious reasons for considering" that an individual was excluded would require an individual to be party to the criminal design, making a significant contribution to the crimes with the intention of

46 Lisa Yarwood "The Tamil $X$ Case", above n 11, at 7.

47 At [110].

$48 X \& Y v$ Refugee Status Appeals Authority, above n 42, at [81].

49 Ibid at [72].

50 At [99].

51 Tamil X v Refugee Status Appeals Authority [2009] NZCA 488, [2010] 2 NZLR 73 at [55].

52 At [105] per Hammond J, [245] per Baragwanath J.

53 R (JS (Sri Lanka)) v Secretary of State for the Home Department [2009] EWCA Civ 364, [2010] 2 WLR 17. 
furthering them. ${ }^{54}$ This was an extension of the Canadian standard used at the lower courts, which required only knowledge of the risk of the crimes. Hammond $\mathrm{J}$ found that there were no "serious reasons for considering" that $\mathrm{X}$ had committed a crime against humanity, as his participation in the voyage, plus the inference that he was aware of the cargo carried by the Yahata, was not enough to show intent to further crimes against humanity. ${ }^{55}$

Arnold $\mathrm{J}$ agreed with Hammond J's finding. He ruled that even if $\mathrm{X}$ was aware of the nature of the cargo, it was not sufficiently certain that the arms would be used for the illegal purpose of action against civilians to find that $\mathrm{X}$ had intent to further the crimes. ${ }^{56}$

Baragwanath J went further, questioning whether it was possible in law to find a joint criminal enterprise, given the uncertainty about the future use of the arms and ammunition. Although it is an international crime to smuggle arms for use against civilians, carrying the arms was not unlawful in itself, since the Tamil Tigers were conducting a legitimate war. ${ }^{57}$ Baragwanath $\mathrm{J}$ found that at most, there was a 50 per cent chance that the arms would be used in an illegal manner, and that, therefore, smuggling these arms would no more than "materially increase the risk" that a crime against humanity would be committed. ${ }^{58}$ Baragwanath $\mathrm{J}$ doubted whether this low threshold was sufficient to establish criminality.

In reference to art $1 \mathrm{~F}(\mathrm{~b})$, the Judges differed on whether there was a political purpose to the crime of the scuttling of the Yahata. Baragwanath and Hammond $\mathrm{JJ}$ found that there was a sufficient link between the act and the political purpose for $\mathrm{X}$ not to be found liable, ${ }^{59}$ while Arnold $\mathrm{J}$ held that the link was too tenuous for the scuttling to be a political crime ${ }^{60}$ Further, both Arnold and Baragwanath JJ doubted whether the evidence of the Indian Supreme Court was sufficient for X to be implicated in the destruction of the Yahata.

\section{TAMIL X IN THE SUPREME COURT}

\section{A Procedural Considerations}

The Supreme Court's unanimous decision, delivered by McGrath J, accepted the RSAA's findings of fact in relation to X, stating that its approach was "a straightforward application of its

\footnotetext{
54 Tamil X v Refugee Status Appeals Authority, above n 51, at [104].

55 At [111].

56 At [170].

57 At [230].

58 At [281].

59 At [124] per Hammond J, [309] per Baragwanath J.

60 At [176].
} 
specialised function", ${ }^{61}$ that its findings were "not unreasonable" 62 and, therefore, not to be reevaluated. The review was, therefore, on the appropriate law on complicity in international crimes.

Interestingly, the Supreme Court suggested that the applicant must establish all elements of a claim to refugee status, including establishing that the applicant is not subject to exclusion under art 1F. ${ }^{63}$ This is inconsistent with the international jurisprudence, and is generally considered an incorrect approach. ${ }^{64}$ However, Lisa Yarwood suggests this was an "unintended" mistake by the Court, ${ }^{65}$ and that responsibility to disentitle a claimant from refugee status "lie[s] elsewhere". ${ }^{66}$

Based on its understanding of the Refugee Convention context and the "difficulties of factfinding" in refugee law cases, ${ }^{67}$ the Court stated that the requirement of "serious reasons for considering" goes beyond mere suspicion, but is not equivalent to either the criminal or civil standard. ${ }^{68}$ Beyond that, the Court adopted Sedley LJ's assertion in Al-Sirri v Secretary of State for the Home Department that "it has to be treated as meaning what it says". 69

\section{$B$ Consideration of $X^{\prime}$ 's Complicity in Crimes Against Humanity}

In the Supreme Court there was no dispute that crimes against humanity were committed by the Tamil Tigers between 1985 and 1996. X's exclusion or otherwise from refugee status was based on his alleged complicity in these crimes.

The Rome Statute of the International Criminal Court was accepted as "authoritative assistance"70 on what constitutes a crime against humanity, consistently with the recommendations of the United Nations High Commissioner for Refugees. ${ }^{71}$ The Supreme Court directly applied the

61 Attorney-General v Tamil X, above n 1, at [43].

62 At [45].

63 At [43].

64 Jillian M Siskind "Complicity in Crimes Against Humanity: The Intersection of International Criminal and Canadian Refugee Law" (2004) 49 Crim LQ 96 at 123.

65 Lisa Yarwood "The Return of Tamil X" [2010] NZLJ 369 at 369.

66 At 369.

67 At [38].

68 At [39].

69 At [39], citing Sedley LJ in Al-Sirri v Secretary of State for the Home Department [2009] EWCA Civ 222 at [33].

70 Attorney-General v Tamil X, above $\mathrm{n}$ 1, at [47].

71 "Guidelines on International Protection: Application of the Exclusion Clauses: Article 1F of the 1951 Convention relating to the Status of Refugees", above n 29, at 23. 
Rome Statute, ${ }^{72}$ using arts 25.3 and 30, read together. Article 25 deals with individual criminal responsibility, and it is art $25.3(\mathrm{~d})$ that is relevant to X's case: ${ }^{73}$

3 In accordance with this Statute, a person shall be criminally responsible and liable for punishment for a crime within the jurisdiction of the Court if that person:

(d) In any other way contributes to the commission or attempted commission of such a crime by a group of persons acting with a common purpose. Such contribution shall be intentional and shall either:

(i) Be made with the aim of furthering the criminal activity or criminal purpose of the group, where such activity or purpose involves the commission of a crime within the jurisdiction of the Court; or

(ii) Be made in the knowledge of the intention of the group to commit the crime;

The requisite mens rea is described in art $30:^{74}$

1 Unless otherwise provided, a person shall be criminally responsible and liable for punishment for a crime within the jurisdiction of the Court only if the material elements are committed with intent and knowledge.

2 For the purposes of this article, a person has intent where:

(a) In relation to conduct, that person means to engage in the conduct;

(b) In relation to a consequence, that person means to cause that consequence or is aware that it will occur in the ordinary course of events.

3 For the purposes of this article, "knowledge" means awareness that a circumstance exists or a consequence will occur in the ordinary course of events. "Know" and "knowingly" shall be construed accordingly.

Under the Rome Statute, international crimes can be committed by direct perpetration, encouraging, inciting, aiding, abetting, or joint criminal enterprise. The Supreme Court adopted these forms of commission, including the three forms of joint criminal enterprise (JCE) from the Prosecutor v Dusko Tadić decision of the International Criminal Tribunal of the former Yugoslavia

72 At [52]-[53].

73 Rome Statute of the International Criminal Court 2187 UNTS 3 (adopted 17 July 1998, entered into force 1 July 2002), art 25.

74 Article 30. 
(ICTY). ${ }^{75}$ JCE will be discussed in detail later in this article; here, it is enough to say that it allows for complicity where the claimant has not committed the crime, but has made a contribution to its commission through participation in a criminal plan, and it is "a form of criminal liability, rather than itself constituting a crime". ${ }^{76}$ It has three forms which require different levels of intent, and the Supreme Court found that X's case involved the most extended form of JCE liability, ${ }^{77}$ which covers those who share the aim of the initial criminal enterprise, but do not have the intent to commit a foreseeable incidental crime.

\section{Consideration of the Relevant Canadian Case Law}

The Court considered the Canadian authority on art 1F, which was ruled to be out-dated by the Court of Appeal. It begins with Ramirez $v$ Canada (Minister of Employment and Immigration) ${ }^{78}$ which does not address the ICTY concept of JCE, but requires "a shared common purpose and the knowledge that all of the parties in question may have of it". ${ }^{79}$ This is expanded in Bargazan $v$ Canada (Minister of Citizenship and Immigration) ${ }^{80}$ which states that "'personal and knowing participation' can be direct or indirect". ${ }^{81}$ Finally, liability does not require a causal connection between the acts of the claimant and the international crimes, ${ }^{82}$ although following Musagera the claimant must have knowledge of the acts that make up the international crime, and risk that their acts contribute to it. ${ }^{83}$ Both the RSAA and the High Court had followed this jurisprudence in X's case, and it has been relied upon as persuasive in previous status determinations in New Zealand. ${ }^{84}$

\section{Consideration of the Relevant English Authority}

The Supreme Court also considered the English jurisprudence followed by the Court of Appeal in its ruling on Tamil X. As discussed, the Court of Appeal had relied on an English Court of Appeal decision. However, the relevant elements of this decision were overturned by the United Kingdom Supreme Court. Therefore, the New Zealand Supreme Court looked instead to the United Kingdom

75 At [54], citing Prosecutor v Dusko Tadić (Judgment) ICTY Appeals Chamber IT-94-1-A, 15 July 1999.

76 Ibid at [55].

77 At [56].

78 Ramirez v Canada (Minister of Employment and Immigration) [1992] 3 FC 306 (FCA).

79 Ibid at 180.

80 Bargazan v Canada (Minister of Citizenship and Immigration) [1996] 205 NR 282 (FCA).

81 At [11].

82 Sumaida v Canada (Minister of Citizenship and Immigration) [2000] 3 FC 66 (FCA).

83 Musagera v Canada (Minister of Citizenship and Immigration), above n 18, at [173].

84 Joseph Rikhof "War Criminals Not Welcome: How Common Law Countries Approach the Phenomenon of International Crimes in the Immigration and Refugee Context" (2009) 21 IJRL 435 at 479. 
Supreme Court's decision, which found that the English Court of Appeal's approach had been too narrow in requiring that an individual make a significant contribution with the intention of furthering the design, ${ }^{85}$ and found instead that what was required to find a claimant excluded was: ${ }^{86}$

... serious reasons for considering him voluntarily to have contributed in a significant way to the

organisation's ability to pursue its purpose of committing war crimes, aware that his assistance will in

fact further that purpose.

Under this ruling, intention to commit "any specifiable crime" is not necessary. ${ }^{87}$ It is sufficient to know of the organisation's crimes and voluntarily make a contribution to their commission. Further, a direct link of causation is not required; what is necessary is an element of personal responsibility, derived from the personal participation of the claimant.

\section{E Conclusions on the Tamil X Case}

On the matter at hand, the Supreme Court concluded that although crimes against humanity were committed by the Tamil Tigers during the relevant period, $\mathrm{X}$ could not be found to be complicit in any of these crimes. ${ }^{88}$ There was not sufficient evidence to find X was part of a JCE on any voyage except the last one. Although his activities on the final voyage of the Yahata were sufficient to find that he was personally responsible as part of a JCE, the scuttling of the vessel and the subsequent failure to deliver the arms meant that there were no specific completed criminal acts of the Tamil Tigers in which $\mathrm{X}$ was complicit. ${ }^{89}$

The Court stated, however, that: ${ }^{90}$

... had it been shown that he participated in voyages where armaments were delivered to the Tamil

Tigers in Sri Lanka and subsequently that organisation committed crimes against humanity, the position would be different.

Having concluded on art $1 \mathrm{~F}(\mathrm{a})$, the Court moved on to deal succinctly with art $1 \mathrm{~F}(\mathrm{~b})$, and to investigate whether the sinking of the Yahata was a serious non-political crime sufficient to exclude $\mathrm{X}$ from refugee status. Before the Supreme Court, whether the crime was serious was not disputed; the Court addressed only whether the crime was political and whether $\mathrm{X}$ was complicit in it.

$85 R$ (JS (Sri Lanka)) v Secretary of State for the Home Department, above n 53, at [123].

$86 R(J S)$ (Sri Lanka) v Secretary of State for the Home Department [2010] UKSC 15, [2011] 1 AC 184 at [38].

87 Ibid at [37].

88 Attorney-General v Tamil X, above n 1, at [79].

89 At [78].

90 At [79]. 
The Court found that whether a crime is non-political for the purposes of the Refugee Convention depends on whether "the character of the offending is predominantly political or is rather that of an ordinary common law crime". ${ }^{91}$ In this case, due to the political nature of the voyage itself, and the specific targeting of the Indian Navy, the crime committed in scuttling the Yahata became "sufficiently connected" to the political aims of the Tamil Tigers to be considered a political crime. ${ }^{92}$

The Court concluded that $X$ was not excluded from refugee status under either art $1 F(a)$ or art $1 \mathrm{~F}(\mathrm{~b})$ and remitted his case to the RSAA for reconsideration.

\section{ANALYSIS OF THE SUPREME COURT'S JUDGMENT}

The decision in the Supreme Court was laudable. The finding that X could not be excluded as there was no completed crime in which he personally was complicit was an important one, and was the product of careful analysis. Moreover, the Supreme Court's action in rejecting "mere membership" of an organisation as sufficient grounds for exclusion from refugee status will allow for status to be determined according to the actions of the applicant, rather than allowing exclusion "by association". ${ }^{93}$ The decision does much to uphold refugees' rights, in applying the Refugee Convention as it was written, rather than "to meet any political imperative". ${ }^{94}$

There are several issues that are not fully addressed in the judgment of the Supreme Court, and so arise for discussion. First, the decision on what precedent to adopt was not explained, and which precedent was in fact applied is unclear. Secondly, the JCE in which X was considered to be personally responsible is ambiguous in the judgment. Thirdly, it is important to consider the relevance of the ICTY jurisprudence to refugee status determinations, given the differences between a finding of international criminality and a finding of exclusion from refugee status.

\section{A Use of Precedent}

This section will consider which jurisdictions were given precedential value in the decision of the Supreme Court, the likely reasons for that weighting, and whether the application of the precedents was successful.

The Supreme Court discussed English, Canadian and ICTY jurisprudence, but did not explain or clarify which of these authorities it accepted and which it rejected. The Court of Appeal clearly stated that the Canadian jurisprudence on art 1F, relied on in the RSAA and in the High Court, was

\footnotetext{
91 At [90].

92 At [96].

93 Pia Zambelli "Problematic trends in the analysis of state protection and article $1 \mathrm{~F}(\mathrm{a})$ exclusion in Canadian refugee law" (2011) 23 IJRL 252 at 258.

94 Lisa Yarwood "The Return of Tamil X", above n 65, at 59.
} 
out-dated, and had been replaced by the new English jurisprudence arising from JS (Sri Lanka). ${ }^{95}$ However, the Supreme Court is much less definitive. The Refugee Convention was made to be interpreted in a "dynamic" manner, ${ }^{96}$ and is expected to be constantly developing. Further, New Zealand is not bound by precedent from any other jurisdiction in this area, though both the Refugee Convention and the courts have an expectation of consistency between nations. ${ }^{97}$ This means that it is important to be certain which legal frameworks apply in New Zealand.

The line of Canadian authority which was dismissed as out-dated at appellate level was introduced by the Supreme Court as having "attempted to define" what more than membership was necessary to find a JCE, ${ }^{98}$ while the words of Lord Brown in (JS) Sri Lanka are cited and affirmed. ${ }^{99}$ Lord Brown's words reflect a principle that the New Zealand Supreme Court viewed as central to a determination; that "those who contribute significantly to the commission of an international crime with the stipulated intention, although not direct perpetrators of it, are personally responsible for the crime". ${ }^{100}$ The Supreme Court adopted this principle, recognising the importance of "maintain[ing] a common approach" to the application of the Refugee Convention internationally. ${ }^{101}$

On a close analysis, the Canadian jurisprudence and the English jurisprudence of the Supreme Court in (JS) Sri Lanka are markedly similar. The Canadian jurisprudence, followed in the RSAA and High Court, looks to the level of "personal participation" of the claimant. Except in "limited, brutal purpose organisations", ${ }^{102}$ membership of an organisation is not enough to find complicity in the Canadian jurisprudence. ${ }^{103}$ Canada uses the Ramirez approach to determine "how the applicant shared in the organisation's common purpose and his or her level of knowledge of the acts of

95 Tamil X v Refugee Status Appeals Authority, above n 51, at [105] per Hammond J, [245] per Baragwanath J.

96 United Nations High Commissioner for Refugees "Guidelines on International Protection: Application of the Exclusion Clauses: Article 1F of the 1951 Convention relating to the Status of Refugees", above n 29, at 23.

97 Ibid.

98 Attorney-General v Tamil X, above n 1, at [58].

99 At [69]-[70].

100 At [70].

101 Ibid.

102 Jillian M Siskind "Complicity in Crimes Against Humanity: The Intersection of International Criminal and Canadian Refugee Law", above n 64, at 123.

103 See generally Joseph Rikhof "War Crimes Law, As Applied in Canada" in Richard Wiggers and Ann Griffiths (eds) Modern Global Crises and War Crimes: Canada, Peacekeeping and International Humanitarian Law (Halifax, Dalhousie University, 2002) 121. 
violence". ${ }^{104}$ Although Ramirez is accepted as correct, ${ }^{105}$ it is frequently misapplied, ${ }^{106}$ leading to exclusion and "guilt by association". ${ }^{107}$ The English jurisprudence, drawn from (JS) Sri Lanka, requires "no more ... than that the accused had personal knowledge of such aims [of committing art $1 \mathrm{~F}$ crimes generally] and intended to contribute to their commission". ${ }^{108}$ It sees the claimant's actual behaviour as the crux of a status decision. ${ }^{109}$ Essentially, the Canadian and English tests both require actual knowing participation in the common criminal purpose.

Both the English and Canadian tests are also similar to the ICTY jurisprudence which states: ${ }^{110}$

The culpable participant would not need to know of each crime committed. Merely knowing that crimes are being committed ... and knowingly participating ... in a way that substantially assists or facilitates the commission of a crime or which allows the criminal enterprise to function effectively or efficiently would be enough to establish criminal liability.

Overall, the Supreme Court looked to ICTY authority to outline the different possible forms of complicity in crimes against humanity, drawing specifics of what level of participation is needed from the Canadian Federal Court cases and using the recent cases from the United Kingdom to define the requisite mental element. Therefore, the Supreme Court's approach is either a melding of the jurisdictions, or an assertion that they are more similar than the Court of Appeal suggests. Unfortunately, the decision lacks the clarity that would make it an effective precedent. However, the Supreme Court does make an effective fusion of the three strands, which may be applied in the future despite the lack of clear justification or explanation.

\section{B Joint Criminal Enterprise}

The Rome Statute provides for international crimes to be committed in a number of ways; these range from direct perpetration, through encouraging and inciting, aiding and abetting, and being part of a JCE. This section will discuss the doctrine of JCE and its application in Tamil X. The Supreme Court found $X$ to be participating in a JCE. This means that he did not directly commit any international crime himself, but was found to be sufficiently complicit in the war crimes of the

104 James C Simeon "Exclusion Under Article 1F(a) of the 1951 Convention in Canada", above n 34, citing James Sloan "The Application of Article 1F of the 1951 Convention in Canada and the United States" (2000)12 IJRL 233.

105 Pia Zambelli "Problematic trends in the analysis of state protection and article 1F(a) exclusion in Canadian refugee law", above n 93 , at 71 .

106 Ibid.

107 Ibid.

108 R (JS) (Sri Lanka) v Secretary of State for the Home Department, above n 86, at [37].

109 Ibid.

110 Prosecutor v Miroslov Kvočka (Judgment) ICTY Trial Chamber IT-98-30, 2 November 2001 at [312]. 
Tamil Tigers to be liable for them. The current conception of a JCE arose in ICTY jurisprudence, and it reflects, to a degree, the common law concept of complicity. However, the requirements for complicity in an international crime are different to the requirements for complicity in a domestic crime, ${ }^{111}$ and are contained in the Rome Statute.

JCE is a highly contested doctrine. ${ }^{112}$ It is the subject of ongoing academic debate, and is often criticised as to its scope, levels of required foreseeability, and links between causation and culpability. ${ }^{113}$ It is also criticised for its attribution of liability to those who do not intend to further the aims of the criminal enterprise. ${ }^{114}$ It is suggested by some commentators that its scope is such that "the legitimacy of international criminal law will be threatened", ${ }^{115}$ as it criminalises too broadly. JCE was developed, and is frequently applied, to allow the ICTY to prosecute high-echelon offenders, ${ }^{116}$ who are too far removed from the crime to be considered accomplices.

The seminal modern case on JCE is Tadić, which addresses the commission of crimes against humanity and breaches of the Geneva Conventions by a low-level member of the paramilitary forces in the former Yugoslavia. ${ }^{117}$ This case outlined the requirements for individual liability for complicity in international crimes. The actus reus for a JCE is fulfilled when "there is a plurality of persons, a common [criminal] plan and participation of the individual in the execution of the common plan". ${ }^{118}$ The plan need not have been specifically arranged, and it can be inferred from the actions of a group. ${ }^{119}$ An individual becomes liable for the actions of the group if he or she

111 Jillian M Siskind "Complicity in Crimes Against Humanity: The Intersection of International Criminal and Canadian Refugee Law", above n 64, at 99.

112 Catherine H Gibson "Testing the Legitimacy of the Joint Criminal Enterprise Doctrine in the ICTY: A Comparison of Individual Liability for Group Conduct in International and Domestic Law" (2008) 18 Duke J Comp \& Int L 521 at 528.

113 Antonio Cassese "The Proper Limits of Individual Responsibility Under the Doctrine of Joint Criminal Enterprise" (2007) 5 JICJ 109.

114 Jens David Ohlin "Three Conceptual Problems with the Doctrine of Joint Criminal Enterprise" (2007) 5 JICJ 69 at 69 .

115 Allison Marston Danner and Jenny S Martinez "Guilty Associations: Joint Criminal Enterprise, Command Responsibility, and the Development of International Criminal Law" (2005) 93 CLR 75 at 132.

116 Catherine H Gibson "Testing the Legitimacy of the Joint Criminal Enterprise Doctrine in the ICTY: A Comparison of Individual Liability for Group Conduct in International and Domestic Law", above n 112, at 523.

117 Prosecutor v Dusko Tadić, above n 75.

118 United Nations High Commissioner for Refugees "Guidelines on International Protection: Application of the Exclusion Clauses: Article 1F of the 1951 Convention relating to the Status of Refugees", above n 29.

119 Catherine H Gibson "Testing the Legitimacy of the Joint Criminal Enterprise Doctrine in the ICTY: A Comparison of Individual Liability for Group Conduct in International and Domestic Law", above n 112, at 524. 
"substantially assisted or significantly affected the furtherance of the goals of the enterprise, with the knowledge that his [or her] acts or omissions facilitated the crimes committed through the enterprise". 120

The ICTY in Tadic noted that "the foundation of criminal responsibility is the principle of personal culpability". ${ }^{121}$ To ensure that this principle was upheld, the ICTY outlined three different modes of mens rea for the commission of an international crime as part of a joint criminal enterprise. The individual can be liable either for acting in pursuance of the criminal purpose with intent which is shared by all the members of the enterprise (JCE I), ${ }^{122}$ or by acting to uphold the institution of a concentration camp (JCE II), ${ }^{123}$ or (JCE III) by acting in: ${ }^{124}$

... a common design to pursue one course of conduct where one of the perpetrators commits an act which, while outside the common design, was nevertheless a natural and foreseeable consequence of the effecting of that common purpose.

The Supreme Court used a JCE analysis in Tamil X, but did not describe the JCE in which it considered X complicit. It merely stated that X was part of a JCE which "involves the third category of responsibility", ${ }^{125}$ without outlining the boundary of the criminal enterprise under consideration. As adopted by the Supreme Court from Cassese, JCE III requires "participants who agree to the main goal ... but do not share the intent that one or more members entertain to also commit crimes incidental to the main concerted crime". ${ }^{126}$ Under such an analysis, in the case at hand, the "main concerted crime" must be the carriage of the arms, and the incidental crime, which $\mathrm{X}$ did not intend, but which must have been foreseeable to $\mathrm{X}$, is the commission of war crimes and crimes against humanity by the Tamil Tigers.

JCE I and JCE III can be seen to be mutually exclusive with regard to X; if JCE I was applied, he must have had intent, shared with the Tamil Tigers, to commit crimes against humanity. However, if JCE III was applied, he must not have shared the intent to commit crimes against humanity, though the crimes were a foreseeable consequence of a crime in which he was complicit. The Supreme Court stated that it was using JCE III and although it never explicitly stated that the

120 Prosecutor v Miroslov Kvočka, above n 110, at [312].

121 Prosecutor v Dusko Tadić, above n 75, at [186].

122 At [196].

123 At [202].

124 At [204].

125 Attorney-General v Tamil X, above n 1, at [56].

126 At [56], citing Antonio Cassese "Amicus Curiae Brief of Antonio Cassese and Members of the Journal of International Criminal Justice on Joint Criminal Enterprise Doctrine" (2009) 20 Crim LF 289 at 294 (emphasis added) [Antonio Cassese "Amicus Curiae Brief"]. 
carriage of arms was the main crime, this is the only understanding that can reasonably be derived from its judgment.

However, under Baragwanath J's analysis in the Court of Appeal, the carriage of arms could not be an international crime. This argument is vital, but it was neither addressed nor overcome by the Supreme Court. $\mathrm{X}$ must be shown to have been participating in a criminal plan before a JCE analysis is available. The scope of liability is only justifiable by considerations of public policy if there was an initial criminal plan. ${ }^{127}$ If the carriage of the arms was a crime, the JCE III analysis can proceed, with the commission of crimes against humanity by the Tamil Tigers as the "incidental" crime. In this case, $\mathrm{X}$ need not be shown to have intended to commit crimes against humanity; their commission need only be foreseeable. However, if the carriage of the arms was legal, it is unjustifiable to derive criminal liability for crimes against humanity from it. ${ }^{128}$

So, was the carriage of the arms by the crew of the Yahata an international crime? In a comprehensive survey of international law on the issue, Baragwanath J concluded that transporting arms for the Tamil Tigers "may not be treated as per se unlawful", 129 because the Tamil Tigers were engaged in a legal war, as well as an illegitimate one. This meant it was as likely as not that the arms would be used for a legitimate military purpose. ${ }^{130}$ Baragwanath $\mathrm{J}$ concluded that therefore "the Crown cannot establish" 131 that the arms would be used for the commission of crimes against humanity, and it is suggested that "without such a finding it was impossible to find that the appellant could have the requisite knowledge needed to satisfy the legal test for those crimes". 132

As stated above, the Supreme Court did not address Baragwanath J's argument, beyond a statement that "it matters not on a test based on joint enterprise principles that the actual cargo might equally have been used only for legitimate purposes in military operations". ${ }^{133}$ This is regrettable, as the correct analysis of the case hinges on which crime $\mathrm{X}$ is seen to be complicit in.

If the carriage of the arms was not an international crime, the JCE must be the commission of crimes against humanity generally by the Tamil Tigers. This means the argument ought to be constructed following an analysis according to JCE I requirements, and X's intention to commit

127 Antonio Cassese "Amicus Curiae Brief", ibid at 297.

128 Ibid.

129 Tamil X v Refugee Status Appeals Authority, above n 51, at [230] per Baragwanath J.

130 Ibid at [278].

131 At [233].

132 Lisa Yarwood "The Tamil $X$ Case", above n 11, at 8.

133 Attorney-General v Tamil X, above n 1, at [71]. 
crimes against humanity must be proved. It was not proved in the case. Rather, through the application of JCE III, it was accepted that X did not have that intent.

There is further confusion in the adoption by the Supreme Court of (JS) Sri Lanka. The facts in that case are very similar. JS was a member of the Tamil Tigers intelligence division who, among other activities, led "a mobile unit responsible for transporting military equipment and other members of the Intelligence Division through jungles"134 so those members could go armed, in plain clothes, to Colombo. He successfully completed this operation for three years, and this was considered to be highly relevant to his status determination. ${ }^{135}$ Unlike Tamil $X$, the case was decided on JCE I principles; the United Kingdom Supreme Court found JS to have the requisite intent to commit war crimes. In the United Kingdom Supreme Court, distinguishing the three different types of JCE liability was dismissed as not "especially helpful". ${ }^{136}$ Although it makes a significant difference to the level of intention required, Lord Brown dismissed the third type of liability as having "no present relevance" to the case, ${ }^{137}$ as he believed that JS was part of a common design with the Tamil Tigers to commit crimes against humanity. Confusingly, the Supreme Court in Tamil $X$ appeared to adopt the English court's principles, without modification, to find liability under JCE III.

The New Zealand Supreme Court did not find that X had actual intent to commit war crimes, and as such could not find him complicit under JCE I. The focus was on his knowledge of the crimes, his foresight and risk-taking, ${ }^{138}$ which were said to be "the necessary elements of the respondent's personal responsibility as part of a joint criminal enterprise". ${ }^{139}$ This certainly implies a discussion of the constructive knowledge required under JCE III. However, an initial crime is required for a JCE III analysis. In X's case, the Supreme Court neglected to prove that the carriage of the arms aboard the Yahata was an international crime, despite an assertion to the contrary by Baragwanath J.

The Supreme Court's application of JCE principles was unclear at best; at worst it could be seen as incorrect. It is unfortunate that there was such a lack of clarity in the application of JCE in this case, as a clear and correct understanding of JCE would be beneficial to making fair and transparent refugee status determinations in the future.

$134 R$ (JS (Sri Lanka)) v Secretary of State for the Home Department, above n 53, at [4].

135 At [28].

136 At [19].

137 Ibid.

138 Attorney General v Tamil X, above n 1, at [71].

139 Ibid. 


\section{ICTY Jurisprudence}

The Supreme Court in Tamil $X$ adopted the ICTY jurisprudence as authority on interpreting the scope of international crimes, and hence in deciding whether or not to exclude a claimant from refugee status. This section will describe the marked differences in the function of the Rome Statute with regard to art $1 \mathrm{~F}$, and the jurisprudence of the ICTY. The role of the ICTY is to ascribe criminal culpability, whereas in refugee status determinations the role of the Rome Statute is as an aid to interpreting the Refugee Convention, in deciding whether or not to grant refugee status. As such, this section will argue that although the ICTY jurisprudence is very useful, the differences are such that some alterations to the jurisprudence are required before it can be appropriately adopted for use in refugee status determinations.

A primary difference is the standard of proof. Judgments in international criminal cases require a finding "beyond reasonable doubt", while, as has repeatedly been stated, the requirement for exclusion from refugee status is "serious reasons for considering" the same crime has been committed. Hathaway points out this means that the applicant for refugee status need not have been formally charged with, or convicted of, any crime ${ }^{140}$ and neither is it necessary to have sufficient evidence for the claimant to be convicted beyond reasonable doubt of the crime at international law. It is enough to have "sufficient proof warranting the assumption of [the claimant's] guilt of such a crime", ${ }^{141}$ a requirement which is not analogous to standards for ordinary judicial proceedings. This leads to significantly different requirements for evidence and certainty in each case. The ICTY jurisprudence, with its low requirements of mens rea and participation, is appropriate only when a criminal standard of proof is required.

Secondly, JCE means that the ICTY can find wide ranging criminal liability. Under JCE I, "all are responsible, whatever their role and position in carrying out the common criminal plan". ${ }^{142}$ Application of this branch has included holding a man liable for waiting in a car while a killing took place. ${ }^{143}$ Under JCE II, responsibility for the crimes committed in a concentration camp is borne if the claimants have "knowledge of the serious abuses being perpetrated and willingly take part in the functioning of the institution". ${ }^{144}$ JCE III arises if a risk of the international crime was foreseen, and the claimant "willingly took the risk"145 that it would occur. It is not required that the outcome is intended, and JCE III has included holding "every person in the crowd who struck a blow" liable for

140 JC Hathaway The Law of Refugee Status, above n 27, at 215.

141 Ibid.

142 Antonio Cassese "Amicus Curiae Brief", above n 126, at 297

143 Otto Sandrock and Three Others [1947] 1 Law Reports of Trials of War Criminals 35 (British Military Court for the Trial of War Criminals) at 41.

144 Antonio Cassese "Amicus Curiae Brief", above n 126, at 297.

145 Ibid at 299. 
the murder of an airman who was the victim of mob violence. ${ }^{146}$ It is a doctrine with an incredibly broad scope.

This scope is justified in the ICTY by the requirement for differential sentencing based on levels of guilt. Cassese argues that it must be possible "to take account of the lesser degree of culpability of the participant", ${ }^{147}$ as compared to the primary offender, at the sentencing stage. This is seen as insufficient justification, even in the criminal context, by several commentators, ${ }^{148}$ who argue that it interferes with proper accounting for individuals' crimes. ${ }^{149}$ In contrast, in refugee status determinations a finding of culpability as a primary, an accomplice, or a member of a JCE leads to the same consequence: exclusion from refugee status. Thus, the justification for the wide scope of actions rendered criminal by the JCE doctrine can only be more contentious with regards to a refugee status determination which does not allow for differential outcomes.

Thirdly, the possible consequences of a finding of complicity also differ greatly between ICTY and refugee status determinations. The ICTY makes findings of criminality and imposes sentences of imprisonment. In contrast, a negative refugee status determination can have as its most severe potential consequences arbitrary deprivation of life, or cruel and inhumane punishment, and such consequences can apply equally to anyone refused refugee status. This is especially important given the recognition that those who are subject to status decisions are generally "from the lower echelons of organizations involved in atrocities", ${ }^{150}$ while those who come before the ICC or ICTY are the highest-level offenders. ${ }^{151}$

The differences between the findings of international criminality in an ICTY decision and findings of exclusion from refugee status are so significant that some changes must be made before the ICTY jurisprudence can properly be adopted as the law applicable to refugee status determinations. These changes will be considered below in Part VIII.

146 Erich Heyer and Six Others [1947] 1 Law Reports of Trials of War Criminals 88 at 88 (British Military Court for the Trial of War Criminals).

147 Antonio Cassese "The Proper Limits of Individual Responsibility Under the Doctrine of Joint Criminal Enterprise", above n 113, at 116.

148 See generally Jens David Ohlin "Three Conceptual Problems with the Doctrine of Joint Criminal Enterprise", above n 114, at 88.

149 Allison Marston Danner and Jenny S Martinez "Guilty Associations: Joint Criminal Enterprise, Command Responsibility, and the Development of International Criminal Law", above n 115, at 142.

150 Joseph Rikhof "Complicity in International Criminal Law and Canadian Refugee Law" (2006) 4 JICJ 702 at 704.

151 Allen O'Rourke "Joint Criminal Enterprise and Brđanin: Misguided Over-Correction" (2006) 47 Harvard Intl LJ 307 at 323. 


\section{POLICY CONSIDERATIONS}

It is important to consider the consequences of the decision in Tamil $X$ for future cases. Although $X$ was not excluded from refugee status, he would have been excluded under art $1 F(a)$ if he had not failed to deliver the arms to Sri Lanka. The Court of Appeal recognised that if he were denied refugee status "the consequences of being returned to Sri Lanka may well be very serious for $\mathrm{X}$ ". ${ }^{152}$ In similar cases, where the claimant would legitimately be found to be a refugee but for a determination of complicity under $1 \mathrm{~F}$, the consequences of a negative determination could extend to refoulement to torture or arbitrary deprivation of life. ${ }^{153}$

Granting refugee status is dependent on a finding that the claimant has a well-founded fear of persecution if returned to his or her nation. Such a determination grants the refugee the protections provided by the Refugee Convention, including protection against refoulement. ${ }^{154}$ In New Zealand, under the Immigration Act 2009, asylum seekers who do not meet the criteria for refugee status under the Refugee Convention have a degree of protection against refoulement, as a designated "protected person", 155 if return will either put their life at risk or put them at risk of torture. This status does not grant them the same rights as refugees. ${ }^{156}$ When the reason for denial of refugee status is exclusion under art $1 \mathrm{~F}$, the protection provided depends solely on the discretion of the Minister of Immigration. ${ }^{157}$ Academic analysis is divided as to what rights regime should be applicable to persons excluded from refugee status under art $1 \mathrm{~F} ;{ }^{158}$ some argue that human rights ought to be seen as "rights, not privileges, and cannot be suspended for bad behaviour", 159 meaning excluded claimants ought to be protected from refoulement. Others, however, argue that a lesser rights regime ought to be applicable, potentially allowing refoulement, dependent on the acts of the asylum seeker. ${ }^{160}$

152 Tamil X v Refugee Status Appeals Authority, above n 51, at [41].

153 James C Simeon "Exclusion Under Article 1F(a) of the 1951 Convention in Canada", above n 34.

154 Refugee Convention, above n 2, art 33

155 Section 130

156 Rodger Haines "Sovereignty Under Challenge - the New Protection Regime in the Immigration Bill 2007" [2009] NZLR 149 at 184.

157 Immigration Act 2009, s 139.

158 See generally Jane McAdam "Human Rights At The Frontier: An International Human Rights Law Perspective On New Zealand's Immigration Legislation: Status Anxiety: The New Zealand Immigration Bill And The Rights of Non-Convention Refugees" [2009] NZLR 239.

159 Ben Saul "Protecting Refugees in the Global 'War on Terror'" (Sydney Law School Research Paper No 08/130, University of Sydney, 2008) at 3 (emphasis in original).

160 Rodger Haines "Sovereignty Under Challenge - the New Protection Regime in the Immigration Bill 2007", above n 156, at 205 . 
Even if refugee status is granted, the protection against refoulement to torture or death is not absolute; it is limited by national security under art 33(2) of the Refugee Convention. ${ }^{161}$ In New Zealand, an extra degree of protection is provided by Zaoui v Attorney-General (No 2), ${ }^{162}$ in which the Supreme Court held that decisions to deport people who were a security risk had to be made consistently with the New Zealand Bill of Rights Act 1991, ${ }^{163}$ and that therefore if deportation was likely to result in death or torture, "a Minister could not set the deportation procedure into train on the basis that the continued presence of a person would constitute a threat to national security". ${ }^{164}$ Academic analysis of the judgment has led some commentators to conclude that this is an indirect acceptance of a prohibition against refoulement to torture as jus cogens. ${ }^{165}$ This would provide protection from refoulement to torture to "protected persons". However, this suggestion was specifically rejected by the Supreme Court in its decision, ${ }^{166}$ for lack of state practice and judicial recognition, ${ }^{167}$ though it found that the prohibition of torture was a peremptory norm, which required protection. ${ }^{168}$ Other analysts argue that the proposition that the absolute protection of the individual's right not to be refouled over the protection of all other citizens in the state, if there are reasonable grounds for finding that the individual is a threat to state security, is not "self-evidently correct". 169

Given the uncertainty of the protection provided by the Immigration Act 2009 and by Zaoui especially to excluded asylum seekers, whose protection against refoulement depends solely on ministerial discretion, a continued vigilance and a restrictive interpretation of the exclusion clauses is required to ensure protection of human rights.

\section{SUGGESTIONS FOR DEVELOPMENT}

This article suggests that two changes are necessary to allow the ICTY jurisprudence on JCE to effectively and appropriately serve in refugee status determinations. The proposed alterations are

161 Immigration Act 2009, s164(3).

162 Zaoui v Attorney-General (No 2) [2005] NZSC 38, [2006] 1 NZLR 289.

163 At [90].

164 Susan Glazebrook "Refugees, Security and Human Rights" (presented to Critical Issues in Regional Refugee Protection Conference, Sydney, March 2010) at 24.

165 Lisa Yarwood "Zaoui and jus cogens" [2006] NZLJ 170 at 171.

166 Zaoui v Attorney-General (No 2), above n 162, at [51].

167 Lisa Yarwood "Zaoui and jus cogens", above n 165, at 170.

168 Ibid at 174.

169 Rodger Haines "National Security and Non-Refoulement in New Zealand: Commentary on Zaoui $v$ Attorney-General (No 2)" in Jane McAdam (ed) Forced Migration, Human Rights and Security (Hart Publishing, Oxford, 2008) at 82. 
based on the differences between the two jurisdictions and the necessity, repeated in the literature, for the exclusion clauses to be interpreted "scrupulously and restrictively", ${ }^{170}$ and applied "only where extreme caution has been exercised", ${ }^{171}$ to best protect genuine refugee claimants.

The first element of this restrictive interpretation would be to limit what constitutes a "significant contribution" to a JCE. It is important for the scope of the word "significant" to be clearly understood, as the outcomes of applications for refugee status will hinge on its meaning, and at present the concept is nebulous and potentially incredibly far-reaching.

A "significant contribution" to international crimes has been held to be required for exclusion from refugee status. Previously in New Zealand, asylum seekers have been excluded from refugee status for complicity in crimes against humanity and war crimes for activities such as forced conscription of children, ${ }^{172}$ and presumed torture of civilians while working for the secret police. ${ }^{173}$ In other jurisdictions, asylum seekers have been excluded for being a Cabinet Member representing an organisation that committed atrocities in Pakistan, ${ }^{174}$ for holding leadership positions in the LTTE, ${ }^{175}$ and for being a cook for the Nigerian army. ${ }^{176}$ Certainly, the latter goes too far. ${ }^{177}$ Perhaps Tamil $X$ also went too far in finding that X's participation, as Chief Engineer of the Yahata, would have made a significant contribution to the Tamil Tigers' crimes against humanity had the arms been delivered. Transporting arms and munitions which may or may not be used for an illegitimate purpose is certainly on the lower end what ought to be considered a "significant contribution". Either way, it is vital to have the limits of what constitutes a "significant contribution" clearly and appropriately defined.

As a second element, the article suggests that the mens rea standard for complicity in JCE when making refugee status decisions ought to be set higher than that required in the ICTY jurisprudence. In the case of Tamil X, the Supreme Court applied the ICTY jurisprudence directly and found that only knowledge of the international crimes committed and recklessness as to the effects of one's acts are required. Given the low requirements of proof, the high consequences of exclusion, and the

170 James C Simeon "Exclusion Under Article 1F(a) of the 1951 Convention in Canada", above n 34.

171 Geoff Gilbert "Current issues in the application of the exclusion clauses" (1 January 2001) The Refugee Law Reader < www.en.refugeelawreader.org $>$ at 2.

172 Refugee Appeal No 1248/93 Re TP RSAA No 1248/93, 31 July 1995.

173 Gabriel Sequeiros Garate v Refugee Status Appeals Authority HC Auckland M826/97, 9 October 1997.

174 Baqri v Canada (Minister of Citizenship and Immigration) 2001 FCT 1096, [2002] 2 FC 85.

175 Sivakumar v Canada (Minister of Employment and Immigration) [1994] 1 FC 433 (FCA).

176 Osayande v Canada (Minister of Citizenship and Immigration) 2002 FCT 368.

177 Pia Zambelli "Problematic trends in the analysis of state protection and article $1 \mathrm{~F}(\mathrm{a})$ exclusion in Canadian refugee law", above n 93, at 271. 
contested nature of the JCE doctrine, this article argues that the mens rea requirement should be higher. Refugee status determinations and ICTY decisions ought to be intentionally differentiated with regard to intent.

This article suggests that the mens rea requirement for determination of refugee status ought to be akin to that expressed by the United Kingdom Court of Appeal in (JS) Sri Lanka, and by the New Zealand Court of Appeal in Tamil X. Rather than recklessness sufficing for a negative determination, it should be necessary to find positive intent to contribute. This would lead the jurisprudence even further from guilt by association, for which the Canadian jurisprudence has been criticised. ${ }^{178}$ It would also require an ever more stringent consideration of the acts of the claimant, and of his mental state, which "ultimately must prove to be the determining factors in any case". ${ }^{179}$

\section{CONCLUSION}

This article addressed Attorney-General $v$ Tamil X, a recent Supreme Court case on refugee status determinations in New Zealand. It is important because it sets out how New Zealand will approach art $1 \mathrm{~F}$ of the Refugee Convention and make its decisions on the exclusion of claimants from refugee status. As claims are increasingly affected by art $1 \mathrm{~F}$ considerations, it is imperative that the law in this complicated area is clear and just. This article traced Tamil X's advancement through the courts, and detailed the findings in the Supreme Court. It also presented an analysis of the Supreme Court's judgment, praising it as laudable, while pointing out some gaps in the clarity of its reasoning. The article also suggested some developments for the jurisprudence that would best serve to appropriately action the exclusion clauses.

In Tamil $X$, the Supreme Court responded to the expectation of the United Nations High Commission on Refugees that the law on refugee status continues to actively develop in response to changes in the international context. ${ }^{180}$ The Supreme Court followed the United Kingdom's adoption of the ICTY jurisprudence as a relevant framework for exclusion cases, and created an effective synthesis of principles from Canada, the United Kingdom and the ICTY. The author sees this as an important step for the clarity, certainty and fairness of future status decisions.

Significant doubt remains about the protection and status provided by the Immigration Act 2009 to excluded asylum seekers, despite their classification as "protected persons". As such, a clear and restrictive interpretation of the exclusion clauses is required. Proper adoption of the ICTY

178 See generally Pia Zambelli, ibid.

179 R (JS) (Sri Lanka) v Secretary of State for the Home Department, above n 86, at [30].

180 United Nations High Commissioner for Refugees "Guidelines on International Protection: Application of the Exclusion Clauses: Article 1F of the 1951 Convention relating to the Status of Refugees", above n 29, at 23. 
jurisprudence on JCE will provide a useful framework for the exercise of the exclusion jurisprudence internationally, though it is not appropriate to adopt it without some alterations.

Therefore, as further developments, the article suggests that the ICTY jurisprudence on JCE can be appropriately applied if two changes are made to it, to recognise the differing purposes of refugee status determinations and ICTY findings of liability. Specifically, a heightened mens rea standard and a clear definition of what constitutes a "significant contribution" to a JCE are necessary to best protect genuine refugee claimants. 
